Communication

\title{
Sensing of C-Reactive Protein Using an Extended-Gate Field-Effect Transistor with a Tungsten Disulfide-Doped Peptide-Imprinted Conductive Polymer Coating
}

\author{
Kai-Hsi Liu ${ }^{1,2,+}$, Hung-Yin Lin ${ }^{3,+}$, James L. Thomas ${ }^{4}$, Chen-Yuan Chen ${ }^{3}$, Yen-Ting Chen ${ }^{5}$, Chuen-Yau Chen ${ }^{1}$, \\ Chien-Hsin Yang $^{3, *}$ and Mei-Hwa Lee ${ }^{6, *}$
}

check for

updates

Citation: Liu, K.-H.; Lin, H.-Y.;

Thomas, J.L.; Chen, C.-Y.; Chen, Y.-T.;

Chen, C.-Y.; Yang, C.-H.; Lee, M.-H.

Sensing of C-Reactive Protein Using

an Extended-Gate Field-Effect

Transistor with a Tungsten

Disulfide-Doped Peptide-Imprinted

Conductive Polymer Coating

Biosensors 2022, 12, 31. https://

doi.org/10.3390/bios12010031

Received: 25 November 2021

Accepted: 3 January 2022

Published: 7 January 2022

Publisher's Note: MDPI stays neutral with regard to jurisdictional claims in published maps and institutional affiliations.

Copyright: (C) 2022 by the authors. Licensee MDPI, Basel, Switzerland. This article is an open access article distributed under the terms and conditions of the Creative Commons Attribution (CC BY) license (https:// creativecommons.org/licenses/by/ $4.0 /)$.
1 Department of Electrical Engineering, National University of Kaohsiung, Kaohsiung 81148, Taiwan; liukaihsi@gmail.com (K.-H.L.); cychen@nuk.edu.tw (C.-Y.C.)

2 Department of Internal Medicine, Division of Cardiology, Zuoying Branch of Kaohsiung Armed Forces General Hospital, Kaohsiung 81342, Taiwan

3 Department of Chemical and Materials Engineering, National University of Kaohsiung, Kaohsiung 81148, Taiwan; linhy@ntu.edu.tw (H.-Y.L.); tp65p4m0@gmail.com (C.-Y.C.)

4 Department of Physics and Astronomy, University of New Mexico, Albuquerque, NM 87131, USA; jthomas@unm.edu

5 Interdisciplinary Program of Electrical Engineering and Computer Science, National Taiwan University of Science and Technology, Taipei 10607, Taiwan; chenyt.daniel@yahoo.com.hk

6 Department of Materials Science and Engineering, I-Shou University, Kaohsiung 84001, Taiwan

* Correspondence: yangch@nuk.edu.tw (C.-H.Y.); meihwalee@ntu.edu.tw (M.-H.L.)

+ These authors contributed equally to this work.

\begin{abstract}
C-reactive protein (CRP) is a non-specific biomarker of inflammation and may be associated with cardiovascular disease. In recent studies, systemic inflammatory responses have also been observed in cases of coronavirus disease 2019 (COVID-19). Molecularly imprinted polymers (MIPs) have been developed to replace natural antibodies with polymeric materials that have low cost and high stability and could thus be suitable for use in a home-care system. In this work, a MIP-based electrochemical sensing system for measuring CRP was developed. Such a system can be integrated with microfluidics and electronics for lab-on-a-chip technology. MIP composition was optimized using various imprinting template (CRP peptide) concentrations. Tungsten disulfide $\left(\mathrm{WS}_{2}\right)$ was doped into the MIPs. Doping not only enhances the electrochemical response accompanying the recognition of the template molecules but also raises the top of the sensing range from $1.0 \mathrm{pg} / \mathrm{mL}$ to $1.0 \mathrm{ng} / \mathrm{mL}$ of the imprinted peptide. The calibration curve of the $\mathrm{WS}_{2}$-doped peptide-imprinted polymer-coated electrodes in the extended-gate field-effect transistor platform was obtained and used for the measurement of CRP concentration in real human serum.
\end{abstract}

Keywords: C-reactive protein; epitope imprinting; tungsten disulfide; electrochemical sensing; human serum

\section{Introduction}

C-reactive protein (CRP) is a ring-shaped pentameric protein that is found in blood plasma. Elevated serum levels of CRP are associated with inflammation and severe disease in bacterial or viral infections [1]. Low-grade inflammation has recently been discovered to increase the risk of cardiovascular disease [2]. A systemic inflammatory response has been observed in cases of coronavirus disease 2019 (COVID-19), and 97.8\% of patients with that disease have CRP concentrations above the normal range [1]. A CRP test may be used to find or monitor conditions that cause inflammation, such as sepsis [3], bowel disease [4], lupus or rheumatoid arthritis [5], and osteomyelitis [6]. CRP has also been implicated in the breakdown of important biological barriers. For example, monomeric CRP can cross the retinal pigment endothelium and may cause macular degeneration through the 
disruption of the outer blood-retinal barrier [7]. Moreover, C-reactive protein (CRP) has been demonstrated to induce blood brain barrier (BBB) disruption in a process involving $\mathrm{NAD}(\mathrm{P}) \mathrm{H}$-oxidase dependent oxidative stress [8]. BBB disruption in patients deceased from sepsis was found to correlate with elevated CRP levels [9].

Molecularly imprinted polymers (MIPs) were developed to generate artificial antibodies at low cost and comparatively high stability for the recognition of biomolecules [10]. Two approaches can be used in preparing MIPs that recognize CRP: The whole protein may be used, or specific peptide epitopes derived from the protein sequence. When using the whole protein, it has been important to recognize that the physiological role of CRP is to bind to lysophosphatidylcholine (lysoPC) expressed on the surface of dead or dying cells, and some types of bacteria (by which CRP activates the complement system via C1q [11]). Thus, using functional monomers that mimic lysoPC is important [12-15]. For example, o(4-nitrophenylphosphoryl) choline (4NPPC) has been employed as the functional monomer in microcontact imprinting CRP [12], 3(4)-vinylbenzyl 12-phosphorylcholine-dodecanoate was designed and synthesized specifically to form CRP-recognizing MIPs [13]. Notably, the template used in all of the aforementioned approaches was whole CRP, not peptide fragments. When using a peptide epitope, there is no reason to expect that a lysoPC mimic would improve performance (since the peptide alone does not bind lysoPC). In this work, we have taken this approach, using a peptide (KESDTSYVSLKAPL, designated pK) as the imprinted epitope.

One decade ago, the chemistry [16], electronic and optoelectronic properties of twodimensional layered transition metal dichalcogenide (TMDC) nanosheets were reviewed [17]. The structure of the TMDC tungsten disulfide $\left(\mathrm{WS}_{2}\right)$ is based on a hexagonal crystal in which each tungsten (W) atom is six-fold coordinated and hexagonally packed between two trigonally coordinated sulfur (S) atoms [18]. It forms layers that are bound by weak van der Waals' interactions [16], and these layered structures usually exhibit strongly anisotropic electrical, chemical, mechanical, and thermal properties [17]. Biological sensing [19] and medical diagnosis [20] using TMDCs were both recently reviewed. Tungsten disulfide has also been used in the detection of small molecules (such as $\mathrm{H}_{2} \mathrm{O}_{2}$ and glucose) [20], DNA, and RNA [19]. Our previous studies have demonstrated the utility of doping TMDCs into MIPs for the ultrasensitive determination of $17 \beta$-estradiol concentration [21]. TMDCs have also been added to optimize the performance of peptide-imprinted conductive polymers as electrochemical sensors [22]. In the present work, CRP peptide-imprinted polymers were synthesized and optimized using various imprinting concentrations of template peptide molecules and doping concentrations of $\mathrm{WS}_{2}$ (Scheme 1). CRP concentrations in real human serum were measured using the extended gate field-effect transistor (EGFET) platform [23,24].

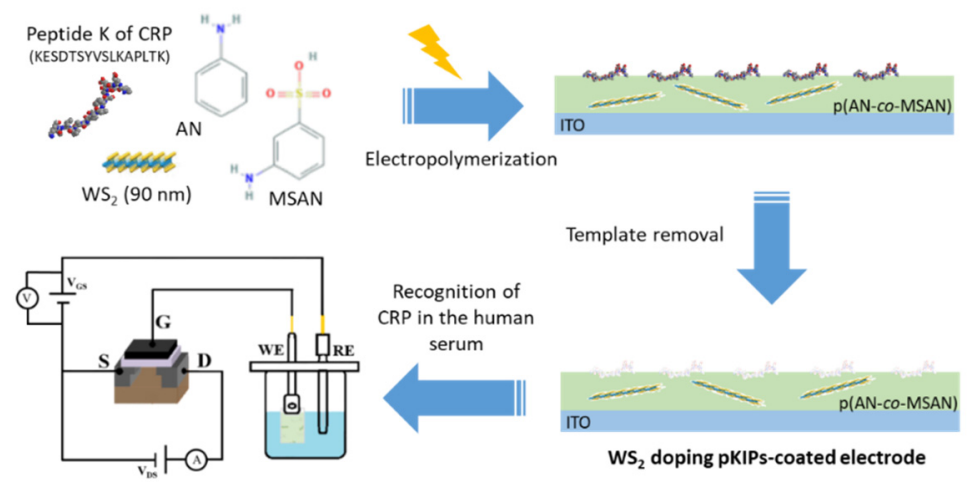

Scheme 1. Sensing of C-reactive protein using a tungsten disulfide-doped peptide-imprinted conductive polymer-coated electrode in an extended-gate field-effect transistor. 


\section{Results and Discussion}

Figure $1 \mathrm{a}, \mathrm{b}$ presents the electropolymerization curves that show the effects of doping $90 \mathrm{~nm} \mathrm{WS} 2$ flakes into poly(AN-co-MSAN), from 0 and $0.5 \mathrm{wt} \%$. There is broad oxidation peak at $0.20-0.25 \mathrm{~V}$ and slightly narrower reduction peak at $-0.05 \mathrm{~V}$. All curves were with a target $\mathrm{pK}$ concentration of $0.5 \mathrm{wt} \%$. The peak currents (both oxidation and reduction) decreased slightly with the increasing concentration of the dopant $\mathrm{WS}_{2}$. Figure $1 c$ shows that higher target $(\mathrm{pK})$ concentrations lead to lower polymerization current (at the 20th polymerization cycle). The current intensity of the oxidation peak decreased approximately exponentially as the amount of added peptide increased, as expected when the peptide competes with $\mathrm{AN}$ for binding to $\mathrm{SO}^{3-}$ on MSAN. Figure $1 \mathrm{~d}$ shows that higher $\mathrm{WS}_{2}$ dopant concentrations have the same effect and also greatly reduce polymerization currents at the 20th cycle. In previous work, we have shown that there is an anticorrelation between polymerization current and sensing current [25]. Therefore, the lower polymerization current should give greater sensing current changes, and thus we selected $\mathrm{pK}$ and $\mathrm{WS}_{2}$ concentrations of $0.5 \mathrm{wt} \%$ for subsequent MIP preparation. Moreover, our previous work also demonstrated the relationship of polymerization duration and the imprinting effectiveness [26] and showed that the thickness of the MIP layer is related to recognition capacity [27].

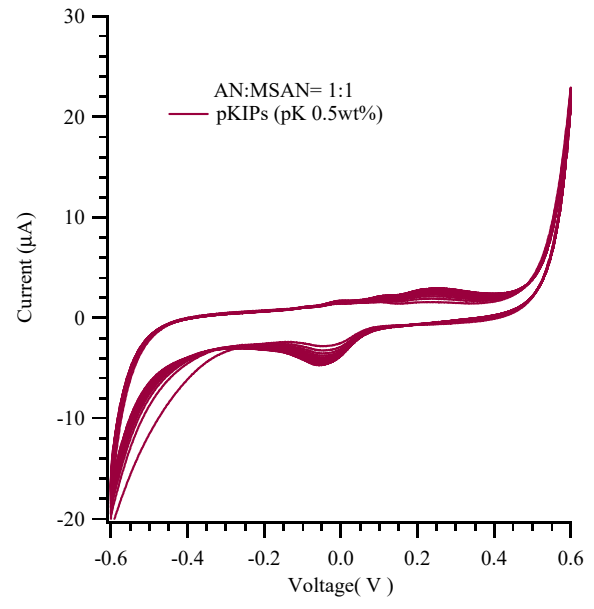

(a)

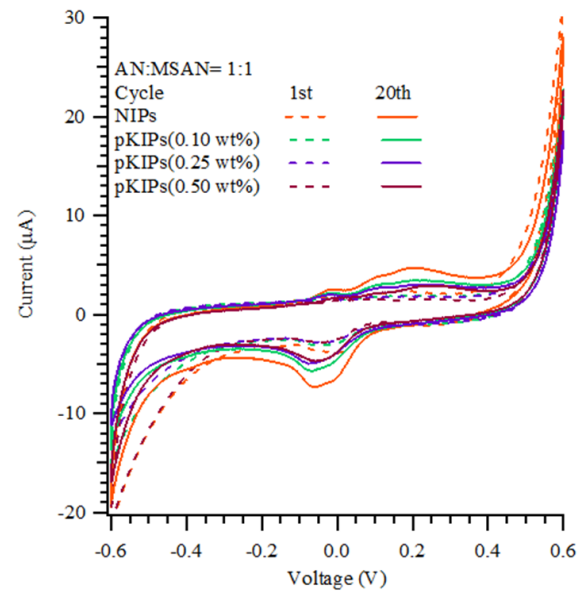

(c)

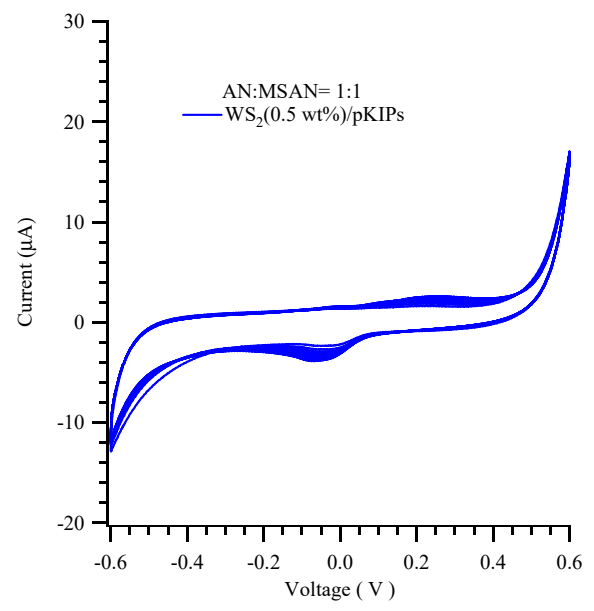

(b)

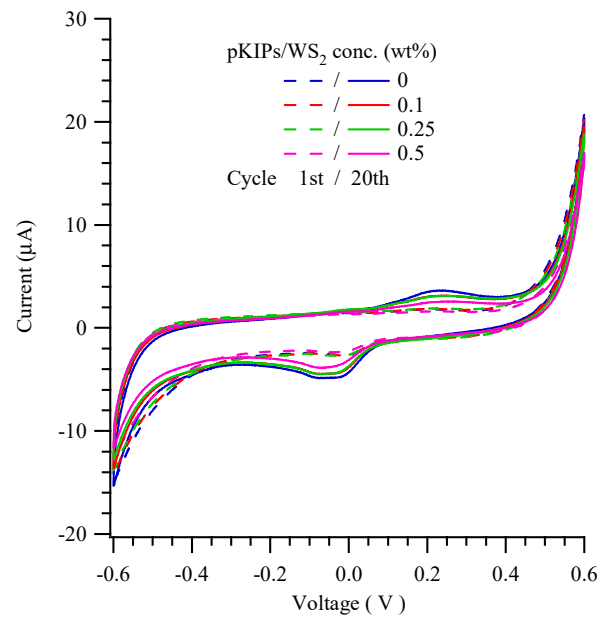

(d)

Figure 1. Cyclic voltammetry of peptide K-imprinted polymers (pKIPs), doped with (a) 0 , (b) $0.50 \mathrm{wt} \%$ of $90 \mathrm{~nm} \mathrm{WS}$ during the electrochemical polymerization. Cyclic voltammetry of the 1st and 20th polymerization cycles during the preparation of peptide-imprinted polymer electrodes with various concentrations of (c) peptides K or (d) $90 \mathrm{~nm} \mathrm{WS}_{2}$. 
Figure 2a,b display the cyclic voltammograms of $\mathrm{WS}_{2} / \mathrm{NIPs}$ - and $\mathrm{WS}_{2} / \mathrm{pKIPs}$-coated electrodes used to sense various peptide $\mathrm{K}$ concentrations in an aqueous solution. The oxidation and reduction current peaks were at 0.2 and $-0.1 \mathrm{~V}$, respectively, possibly corresponding to the oxidation and reduction of coupled $\mathrm{Fe}(\mathrm{CN}) 6^{3+}$ and $\mathrm{Fe}(\mathrm{CN})_{6}{ }^{4+}$. Figure $2 \mathrm{c}$ shows the calibration curves obtained from the voltammograms in Figure 2a,b. The calibration curves plot the difference between the peak current obtained in a pK (target) solution and that obtained in buffer alone for $\mathrm{pK}$ concentrations varying over seven orders of magnitude. The pKIP- and NIP-coated electrodes began to show an onset of saturation (i.e., a leveling-off of the response) beginning at about $1.0 \mathrm{pg} / \mathrm{mL}$, Figure 2c. Doping with $\mathrm{WS}_{2}$ increases the amplitude of the response but also extends the (log)-linearity and useful sensing range up to at least $1.0 \mathrm{ng} / \mathrm{mL}$. Figure $2 \mathrm{~d}$ shows the responses of $\mathrm{WS}_{2}$-doped pK-imprinted electrodes to other peptides taken from CRP sequences. The response of the electrode to these irrelevant peptides is very similar to the responses obtained with non-imprinted electrodes to $\mathrm{pK}$. This is an important result that we will discuss further, vide infra.

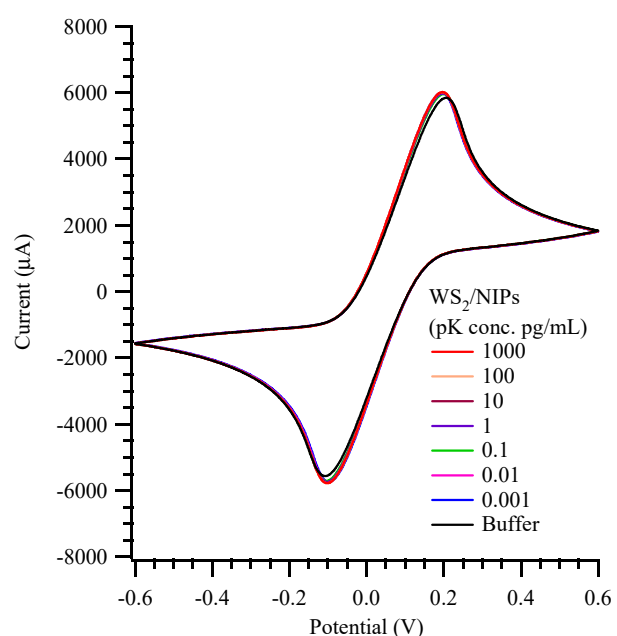

(a)

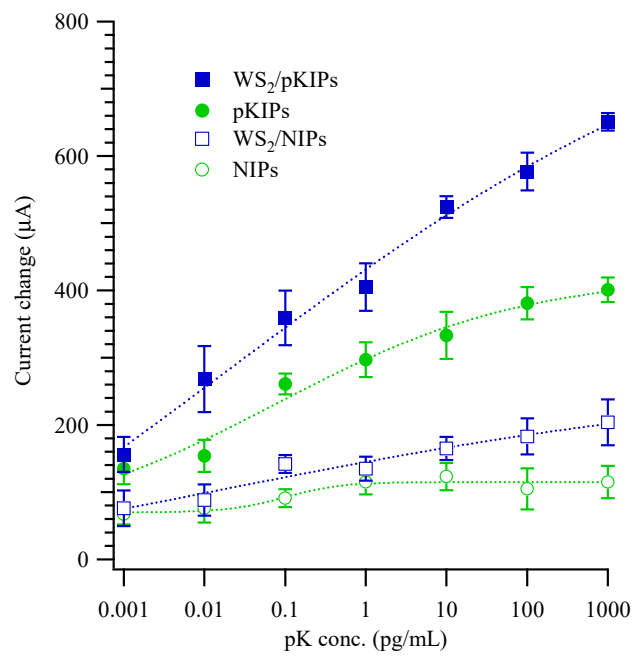

(c)

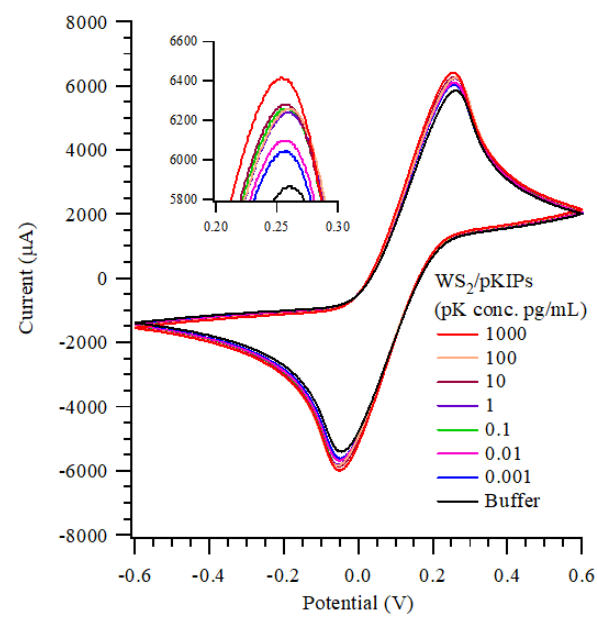

(b)

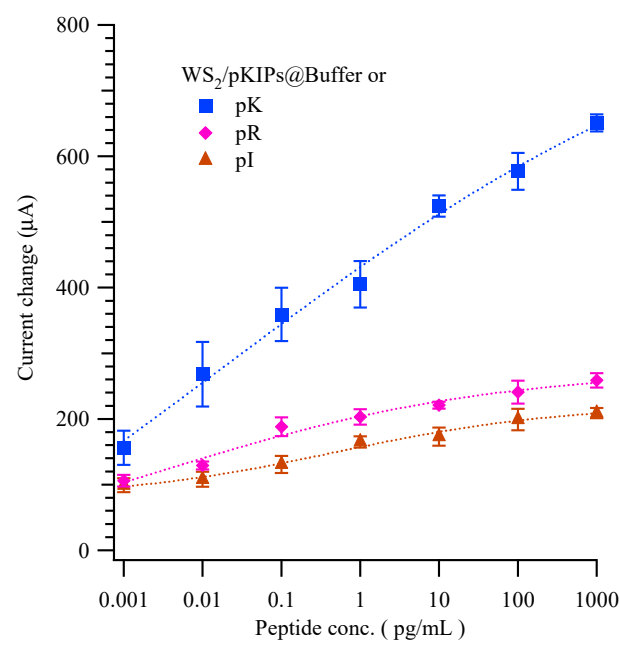

(d)

Figure 2. Cyclic voltammograms of various peptide $\mathrm{K}$ concentrations using (a) $\mathrm{WS}_{2}$-doped NIPsand (b) $\mathrm{WS}_{2}$-doped pKIPs-coated electrodes. (c) Peak oxidation currents (at 0.19 0.21 V), relative to that obtained with buffer, when electrodes were immersed in solutions containing target peptide $\mathrm{pK}$ at concentrations varying over seven orders of magnitude, using the electrodes shown in $(\mathbf{a}, \mathbf{b})$. (d) Interference of CRP $\mathrm{pR}$ and pI peptides on the $\mathrm{WS}_{2}$-doped pKIPs-coated electrode. 
Figure S1, from top to bottom, displays the surface morphologies of $\mathrm{WS}_{2} / \mathrm{NIPs}$ - (left column) and $\mathrm{WS}_{2} /$ pKIPs- (right column) coated electrodes before and after template removal and upon rebinding with $1.0 \mathrm{pg} / \mathrm{mL}$ of $\mathrm{pK}$. The sizes of aggregates of poly(ANco-MSAN) is approximately 50 to $100 \mathrm{~nm}$. Figure S2a,b plot the electrochemical responses of $\mathrm{WS}_{2} / \mathrm{NIPs}$ - and $\mathrm{WS}_{2} / \mathrm{pKIPs}$-coated electrodes in buffer, $1.0 \mathrm{pg} / \mathrm{mL}$ of peptide $\mathrm{K}$ and $1.0 \mathrm{pg} / \mathrm{mL}$ of CRP at various scan rates. These were fit using the Randles-Sevcik equation. Interestingly, the gradients of the fitted curves for $\mathrm{WS}_{2} / \mathrm{pKIPs}$ exceed those for $\mathrm{WS}_{2} / \mathrm{NIPs}_{\text {, }}$ possibly indicating that the binding of $\mathrm{pK}$ or CRP increased the surface area of the electrodes. The larger surface area raises the concern that the higher responses in Figure $2 \mathrm{c}$ arise from non-specific binding to a larger surface area. If this were so, irrelevant peptides would also give strong electrochemical signals. However, as Figure $2 \mathrm{~d}$ shows, irrelevant peptides do not give strong signals with the imprinted electrode, showing that increased surface does not give a larger signal from non-specific binding and that the $\mathrm{WS}_{2} / \mathrm{pKIPs}$-coated electrodes are selective for the imprinted target. Figure S2c plots the AC impedance measurements of $\mathrm{WS}_{2}$-doped pKIPs and NIPs in buffer, peptide $\mathrm{K}$ and CRP $1.0 \mathrm{pg} / \mathrm{mL}$ solutions. The resistance of pKIPs was almost the same as that of NIPs, but decreased upon the rebinding of $\mathrm{pK}$ and CRP. Finally, Figure S2d presents the reusability of the $\mathrm{WS}_{2} / \mathrm{pKIPs}$-coated electrodes. One of those electrodes was used to measure the relative peak current changes of a $1.0 \mathrm{pg} / \mathrm{mL}$ solution of CRP, rinsed, and then reused five times. There was only a small deterioration in the response on the fifth and sixth usage.

Finally, the pKIP-coated electrode was integrated into an extended-gate FET as shown in Scheme 1. The drain current was measured as a function of drain voltage (Figure 3a) for both $\mathrm{WS}_{2}$-doped pKIPs and $\mathrm{WS}_{2}$-doped NIPs at $1.0 \mathrm{pg} / \mathrm{mL}$ CRP concentration and in buffer alone. By repeating the measurement with several different CRP concentrations, a calibration curve of drain current (above buffer only) vs. CRP concentration was constructed, Figure 3b. Interestingly, the electrochemical response (sensitivity) of pK on $\mathrm{WS}_{2} / \mathrm{pKIP}$-coated electrodes is higher on the FET platform than in the cyclic voltammogram in Figure 3a. The calibration curve (Figure 3b) on the FET platform was then used to make measurements of the real serum sample. The sensing range is from $1.0 \mathrm{fg} / \mathrm{mL}$ to $1.0 \mathrm{ng} / \mathrm{mL}$, which is comparable with the MIPs using PC analogs as functional monomers (e.g., 2-acryl amidoethyldihydrogen phosphate [14] or 4NPPC/polyethylene glycol 400 dimethacrylate [15], which gave sensing ranges of 0.07-8.50 and 5-120 $\mathrm{gg} / \mathrm{mL}$, respectively, using differential pulse voltammetry or circular dichroism). Other imprinted CRP sensor approaches include whole CRP imprinted coupled with gold-platinum bimetallic nanomaterials to enhance the sensor's surface area and catalytic activity. This sensor had a large range (0.1-500 $\mathrm{nM}$ or $12 \mathrm{ng} / \mathrm{mL}-60 \mu \mathrm{g} / \mathrm{mL})$ but a much higher limit of detection than the sensor in this work [28]. A graphdiyne-based CRP MIPs biosensor performed with a very broad detection range from $10^{-5}$ to $10^{3} \mathrm{ng} / \mathrm{mL}$ [29]. The $\mathrm{WS}_{2} / \mathrm{pKIP-coated} \mathrm{electrode} \mathrm{in} \mathrm{this} \mathrm{work}$ outperforms (in sensitivity) a CRP immunosensor (with sensing range $0.01-1000 \mathrm{ng} / \mathrm{mL}$ ), which uses antibodies to recognize target molecules [30]. Moreover, our recent study shows that the effect of doping of MIPs with a very small percentage of an MXene (e.g., $\mathrm{Ti}_{2} \mathrm{C}$ at $0.1 \mathrm{wt} \%$ in the preparation solution) can give an electrochemical sensing range from 0.1 to $10,000 \mathrm{fg} / \mathrm{mL}$ [31]. The doping of $\mathrm{WS}_{2}$ nanoflakes in this work may further extend the sensing range. Table 1 shows measurements on a real serum sample. A peak current change of $694.2 \pm 1.2 \mu \mathrm{A}$ was found, which converts to a CRP concentration of around $2.28 \pm 0.12 \mu \mathrm{g} / \mathrm{mL}$. The CRP concentration in the serum sample was checked using ELISA, indicating that the pKIP FET measurement had an accuracy of approximately $96 \%$. 


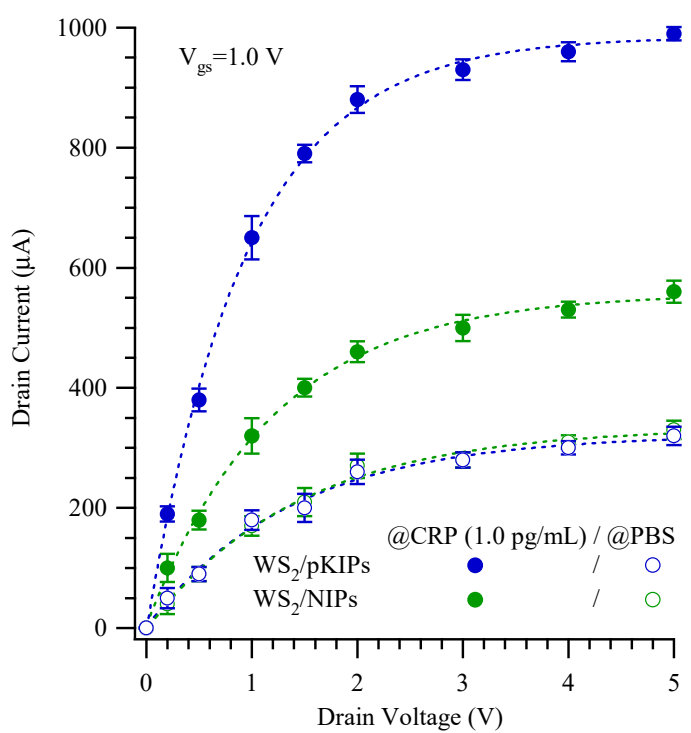

(a)

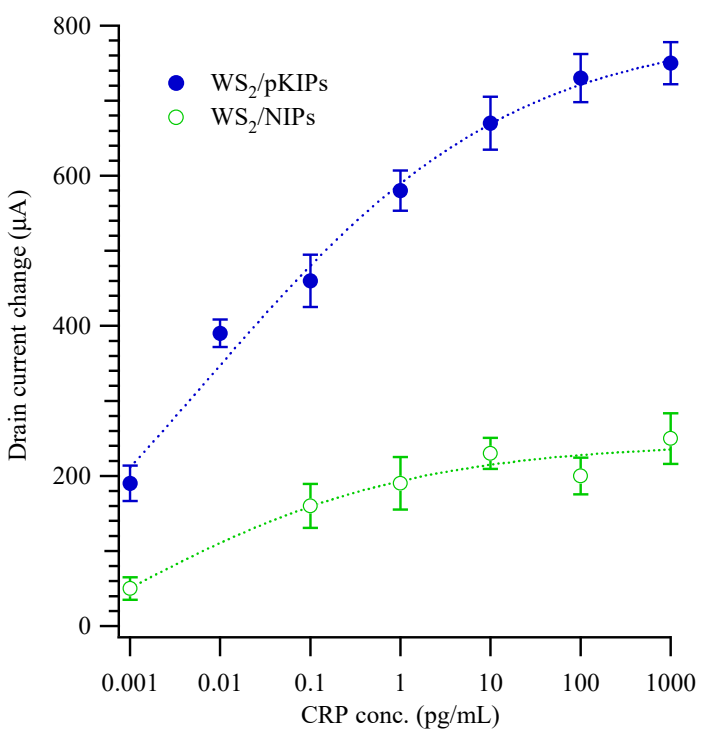

(b)

Figure 3. (a) Electrochemical response of $\mathrm{WS}_{2}$-doped peptide K-imprinted p(AN-co-MSAN)-coated electrodes in CRP and PBS with various drain voltages. (b) Calibration curves measured with tungsten disulfide doping peptide K-imprinted $\mathrm{p}(\mathrm{AN}$-co-MSAN)-coated extended-gate field-effect transistor. The voltage between drain or gate and source electrodes are 1.5 and $1.0 \mathrm{~V}$, respectively.

Table 1. Measurements of CRP in human serum by the $\mathrm{WS}_{2} / \mathrm{pKIPs}$-coated sensors and ELISA kit. The standard deviations are based on at least three individual measurements.

\begin{tabular}{|c|c|c|c|c|c|}
\hline \multirow{2}{*}{ No. } & \multirow{2}{*}{$\begin{array}{c}\mathrm{WS}_{2} / \mathrm{pKIPs} \\
(\mu \mathrm{A})\end{array}$} & \multirow{2}{*}{$\begin{array}{l}\text { Converted conc. } \\
(\mu \mathrm{g} / \mathrm{mL})\end{array}$} & \multicolumn{2}{|c|}{ Average CRP conc. $(\mu \mathrm{g} / \mathrm{mL})$} & \multirow{2}{*}{$\begin{array}{c}\text { Accuracy } \\
(\%)\end{array}$} \\
\hline & & & $\mathrm{WS}_{2} / \mathrm{pKIPs}$ & ELISA & \\
\hline 1 & 694 & 2.26 & & & \\
\hline 2 & 695 & 2.36 & & & \\
\hline 3 & 693 & 2.16 & $2.28 \pm 0.12$ & $2.37 \pm 0.20$ & 96 \\
\hline 4 & 696 & 2.46 & & & \\
\hline 5 & 693 & 2.16 & & & \\
\hline
\end{tabular}

\section{Conclusions}

We constructed a sensitive FET-based sensor for CRP, using peptide epitope imprinting (imprinting a peptide rather than a whole protein). This approach obviates the need to use ligand-mimicking functional monomers in the MIP composition. Flaked tungsten disulfide was used as a dopant in the recognition polymer, which was seen to increase both the response and the useful sensing range. The sensor proved to be sensitive and accurate on real serum when compared to ELISA results. Such economic approaches to biomarker sensing may be cost-effective for future home-care diagnostic systems, which can be integrated with a potentiostat [32] and a microfluidic device [33] or for wearable biosensor devices.

Supplementary Materials: The following are available online at https:/ / www.mdpi.com/article/ 10.3390/bios12010031/s1, Figure S1: SEM images of $90 \mathrm{~nm} \mathrm{WS}_{2}(0.5 \mathrm{wt} \%)$ doped (a) NIPs, and (b) peptide K-imprinted poly(AN-co-MSAN)-coated electrodes before template removal (a,b), after template removal $(\mathrm{c}, \mathrm{d})$, and after rebinding peptide $\mathrm{K}(\mathrm{e}, \mathrm{f})$; Figure S2: The electrochemical response of (a) $\mathrm{WS}_{2} / \mathrm{NIPs}$ and (b) $\mathrm{WS}_{2} / \mathrm{pKIPs}$-coated electrodes in buffer, $1.0 \mathrm{pg} / \mathrm{mL}$ of $\mathrm{pK}$ or CRP. The responses were then fit with Randles-Sevcik equation for the solution at $25^{\circ} \mathrm{C}$, ip $=268,600 \mathrm{n}^{3 / 2}$ $\mathrm{AD}^{1 / 2} \mathrm{Cv}^{1 / 2}$. (c) $\mathrm{AC}$ impedance measurements for $\mathrm{WS}_{2} / \mathrm{NIPs}$ - and $\mathrm{WS}_{2} / \mathrm{pKIPs}$-coated electrodes in buffer, $1.0 \mathrm{pg} / \mathrm{mL}$ of $\mathrm{pK}$ or CRP solutions. (d) The reusability of the $\mathrm{WS}_{2} / \mathrm{NIPs}$ and $\mathrm{WS}_{2} / \mathrm{pKIPs}$ - 
coated electrodes. The electrode was used to measure a $1.0 \mathrm{ng} / \mathrm{mL}$ solution of CRP, rinsed and reused for five cycles.

Author Contributions: Conceptualization, K.-H.L., H.-Y.L., J.L.T., C.-Y.C. (Chuen-Yau Chen), C.-H.Y. and M.-H.L.; methodology, H.-Y.L., C.-H.Y. and M.-H.L.; validation, K.-H.L., H.-Y.L., J.L.T., C.-Y.C. (Chen-Yuan Chen), Y.-T.C., C.-Y.C. (Chuen-Yau Chen), C.-H.Y. and M.-H.L.; investigation, K.-H.L., H.-Y.L., J.L.T., C.-Y.C. (Chen-Yuan Chen), C.-H.Y. and M.-H.L.; resources, H.-Y.L., C.-Y.C. (Chuen-Yau Chen) and C.-H.Y.; data curation, K.-H.L., C.-Y.C. (Chen-Yuan Chen) and Y.-T.C.; writing-original draft preparation, K.-H.L., H.-Y.L., C.-H.Y.; writing-review and editing, K.-H.L., H.-Y.L., J.L.T. and M.-H.L.; visualization, K.-H.L., H.-Y.L., C.-Y.C. (Chen-Yuan Chen) and M.-H.L.; supervision, C.-H.Y. and M.-H.L.; project administration, K.-H.L., H.-Y.L., and M.-H.L.; funding acquisition, K.-H.L., H.-Y.L. and M.-H.L. All authors have read and agreed to the published version of the manuscript.

Funding: This research was funded by Ministry of Science and Technology of ROC under Contract nos. MOST 107-2923-M-390-001-MY3, MOST 108-2923-B-390-001-MY3, MOST 109-2314-B-390-001MY3, 110-2221-E-214-012, MOST 110-2221-E-214-012- and MOST 110-2221-E-390-003-MY3; and the Zuoying Branch of Kaohsiung Armed Forces General Hospital under Contract no. KAFGHZY_A_111003.

Institutional Review Board Statement: Not applicable.

Informed Consent Statement: Not applicable.

Data Availability Statement: The authors confirm that the data supporting the findings of this study are available within the article and its Supplementary Materials.

Conflicts of Interest: The authors declare no conflict of interest.

\section{References}

1. Smilowitz, N.R.; Kunichoff, D.; Garshick, M.; Shah, B.; Pillinger, M.; Hochman, J.S.; Berger, J.S. C-reactive protein and clinical outcomes in patients with COVID-19. Eur. Heart J. 2021, 42, 2270-2279. [CrossRef] [PubMed]

2. Lawler, P.R.; Bhatt, D.L.; Godoy, L.C.; Lüscher, T.F.; Bonow, R.O.; Verma, S.; Ridker, P.M. Targeting cardiovascular inflammation: Next steps in clinical translation. Eur. Heart J. 2021, 42, 113-131. [CrossRef] [PubMed]

3. Póvoa, P.; Almeida, E.; Moreira, P.; Fernandes, A.; Mealha, R.; Aragão, A.; Sabino, H. C-reactive protein as an indicator of sepsis. Intensive Care Med. 1998, 24, 1052-1056. [CrossRef] [PubMed]

4. Vermeire, S.; Van Assche, G.; Rutgeerts, P. C-reactive protein as a marker for inflammatory bowel disease. Inflamm. Bowel Dis. 2004, 10, 661-665. [CrossRef]

5. Shadick, N.A.; Cook, N.R.; Karlson, E.W.; Ridker, P.M.; Maher, N.E.; Manson, J.E.; Buring, J.E.; Lee, I.-M. C-Reactive Protein in the Prediction of Rheumatoid Arthritis in Women. Arch. Intern. Med. 2006, 166, 2490-2494. [CrossRef]

6. Lavery, L.A.; Ahn, J.; Ryan, E.C.; Bhavan, K.; Oz, O.K.; La Fontaine, J.; Wukich, D.K. What are the Optimal Cutoff Values for ESR and CRP to Diagnose Osteomyelitis in Patients with Diabetes-related Foot Infections? Clin. Orthop. Relat. Res. 2019, 477, 1594-1602. [CrossRef] [PubMed]

7. Romero-Vázquez, S.; Adán, A.; Figueras-Roca, M.; Llorenç, V.; Slevin, M.; Vilahur, G.; Badimon, L.; Dick, A.D.; Molins, B. Activation of C-reactive protein proinflammatory phenotype in the blood retinal barrier in vitro: Implications for age-related macular degeneration. Aging 2020, 12, 13905-13923. [CrossRef] [PubMed]

8. Closhen, D.; Bender, B.; Luhmann, H.J.; Kuhlmann, C.R.W. CRP-induced levels of oxidative stress are higher in brain than aortic endothelial cells. Cytokine 2010, 50, 117-120. [CrossRef] [PubMed]

9. $\quad$ Erikson, K.; Tuominen, H.; Vakkala, M.; Liisanantti, J.H.; Karttunen, T.; Syrjälä, H.; Ala-Kokko, T.I. Brain tight junction protein expression in sepsis in an autopsy series. Crit Care 2020, 24, 385. [CrossRef]

10. Lee, S.W.; Kunitake, T. Handbook of Molecular Imprinting: Advanced Sensor Applications; CRC Press: Boca Raton, FL, USA, 2012.

11. Thompson, D.; Pepys, M.B.; Wood, S.P. The physiological structure of human C-reactive protein and its complex with phosphocholine. Structure 1999, 7, 169-177. [CrossRef]

12. Chou, P.-C.; Rick, J.; Chou, T.-C. C-reactive protein thin-film molecularly imprinted polymers formed using a micro-contact approach. Anal. Chim. Acta 2005, 542, 20-25. [CrossRef]

13. Kim, E.; Kim, H.-C.; Lee, S.G.; Lee, S.J.; Go, T.-J.; Baek, C.S.; Jeong, S.W. C-Reactive protein-directed immobilization of phosphocholine ligands on a solid surface. Chem. Commun. 2011, 47, 11900-11902. [CrossRef] [PubMed]

14. Kumar, D.; Prasad, B.B. Multiwalled carbon nanotubes embedded molecularly imprinted polymer-modified screen printed carbon electrode for the quantitative analysis of C-reactive protein. Sens. Actuators B Chem. 2012, 171-172, 1141-1150. [CrossRef]

15. Hong, C.-C.; Chen, C.-P.; Horng, J.-C.; Chen, S.-Y. Point-of-care protein sensing platform based on immuno-like membrane with molecularly-aligned nanocavities. Biosens. Bioelectron. 2013, 50, 425-430. [CrossRef] [PubMed] 
16. Chhowalla, M.; Shin, H.S.; Eda, G.; Li, L.-J.; Loh, K.P.; Zhang, H. The chemistry of two-dimensional layered transition metal dichalcogenide nanosheets. Nat. Chem. 2013, 5, 263-275. [CrossRef]

17. Wang, Q.H.; Kalantar-Zadeh, K.; Kis, A.; Coleman, J.N.; Strano, M.S. Electronics and optoelectronics of two-dimensional transition metal dichalcogenides. Nat. Nanotechnol. 2012, 7, 699-712. [CrossRef]

18. Zhang, Y.; Zhang, Y.; Ji, Q.; Ju, J.; Yuan, H.; Shi, J.; Gao, T.; Ma, D.; Liu, M.; Chen, Y. Controlled growth of high-quality monolayer WS2 layers on sapphire and imaging its grain boundary. ACS Nano 2013, 7, 8963-8971. [CrossRef]

19. Hu, H.; Zavabeti, A.; Quan, H.; Zhu, W.; Wei, H.; Chen, D.; Ou, J.Z. Recent advances in two-dimensional transition metal dichalcogenides for biological sensing. Biosens. Bioelectron. 2019, 142, 111573. [CrossRef]

20. Meng, S.; Zhang, Y.; Wang, H.; Wang, L.; Kong, T.; Zhang, H.; Meng, S. Recent advances on TMDCs for medical diagnosis. Biomaterials 2021, 269, 120471. [CrossRef]

21. Lee, M.-H.; Thomas, J.L.; Su, Z.-L.; Zhang, Z.-X.; Lin, C.-Y.; Huang, Y.-S.; Yang, C.-H.; Lin, H.-Y. Doping of transition metal dichalcogenides in molecularly imprinted conductive polymers for the ultrasensitive determination of $17 \beta$-estradiol in eel serum. Biosens. Bioelectron. 2020, 150, 111901. [CrossRef]

22. Lee, M.-H.; Thomas, J.L.; Su, Z.-L.; Yeh, W.-K.; Monzel, A.S.; Bolognin, S.; Schwamborn, J.C.; Yang, C.-H.; Lin, H.-Y. Transition metal dichalcogenides to optimize the performance of peptide-imprinted conductive polymers as electrochemical sensors Microchim. Acta 2021, 188, 1-11. [CrossRef] [PubMed]

23. Pullano, S.A.; Critello, C.D.; Mahbub, I.; Tasneem, N.T.; Shamsir, S.; Islam, S.K.; Greco, M.; Fiorillo, A.S. EGFET-Based Sensors for Bioanalytical Applications: A Review. Sensors 2018, 18, 4042. [CrossRef]

24. Iskierko, Z.; Sosnowska, M.; Sharma, P.S.; Benincori, T.; D'Souza, F.; Kaminska, I.; Fronc, K.; Noworyta, K. Extended-gate field-effect transistor (EG-FET) with molecularly imprinted polymer (MIP) film for selective inosine determination. Biosens. Bioelectron. 2015, 74, 526-533. [CrossRef]

25. Lee, M.H.; Thomas, J.L.; Su, Z.L.; Yeh, W.K.; Monzel, A.S.; Bolognin, S.; Schwamborn, J.C.; Yang, C.H.; Lin, H.Y. Epitope imprinting of alpha-synuclein for sensing in Parkinson's brain organoid culture medium. Biosens. Bioelectron. 2021, 175, 112852. [CrossRef]

26. Lee, M.-H.; O’Hare, D.; Guo, H.-Z.; Yang, C.-H.; Lin, H.-Y. Electrochemical sensing of urinary progesterone with molecularly imprinted poly(aniline-co-metanilic acid)s. J. Mater. Chem. B 2016, 4, 3782-3787. [CrossRef] [PubMed]

27. Luo, S.-C.; Thomas, J.L.; Guo, H.-Z.; Liao, W.-T.; Lee, M.-H.; Lin, H.-Y. Electrosynthesis of Nanostructured, Imprinted Poly(hydroxymethyl 3,4-ethylenedioxythiophene) for the Ultrasensitive Electrochemical Detection of Urinary Progesterone. ChemistrySelect 2017, 2, 7935-7939. [CrossRef]

28. Balayan, S.; Chauhan, N.; Chandra, R.; Jain, U. Electrochemical Based C-Reactive Protein (CRP) Sensing Through Molecularly Imprinted Polymer (MIP) Pore Structure Coupled with Bi-Metallic Tuned Screen-Printed Electrode. Biointerface Res. Appl. Chem. 2022, 6, 38. [CrossRef]

29. Cui, M.; Che, Z.; Gong, Y.; Li, T.; Hu, W.; Wang, S. A graphdiyne-based protein molecularly imprinted biosensor for highly sensitive human C-reactive protein detection in human serum. Chem. Eng. J. 2021, 431, 133455. [CrossRef]

30. Dong, S.; Zhang, D.; Cui, H.; Huang, T. ZnO/porous carbon composite from a mixed-ligand MOF for ultrasensitive electrochemical immunosensing of C-reactive protein. Sens. Actuators B Chem. 2019, 284, 354-361. [CrossRef]

31. Lee, M.-H.; Liu, K.-H.; Thomas, J.L.; Chen, C.-Y.; Chen, C.-Y.; Yang, C.-H.; Lin, H.-Y. Doping of MXenes enhances the electrochemical response of peptideimprinted conductive polymers for the recognition of C-Reactive protein. Biosens. Bioelectron. 2022, 200, 113930. [CrossRef]

32. Huang, C.-Y.; O'Hare, D.; Chao, I.-J.; Wei, H.-W.; Liang, Y.-F.; Liu, B.-D.; Lee, M.-H.; Lin, H.-Y. Integrated potentiostat for electrochemical sensing of urinary 3-hydroxyanthranilic acid with molecularly imprinted poly (ethylene-co-vinyl alcohol). Biosens. Bioelectron. 2015, 67, 208-213. [CrossRef] [PubMed]

33. Lee, M.-H.; O’Hare, D.; Chen, Y.-L.; Chang, Y.-C.; Yang, C.-H.; Liu, B.-D.; Lin, H.-Y. Molecularly imprinted electrochemical sensing of urinary melatonin in a microfluidic system. Biomicrofluidics 2014, 8, 054115. [CrossRef] [PubMed] 